\title{
The Events in 1992
}

Abstract This chapter deals with how and why the war emerges in Bosnia and how the involved actors acted. Serbian and Croatian leadership with Slobodan Milošević and Radovan Karadžić, respectively, pushed for hostilities all when the leadership in Bosnia with Alija Izetbegović and parts of the international community as Germany did little to avert the coming disaster.

Keywords Bosnia $\cdot$ Serbia $\cdot$ Croatia $\cdot$ Alija Izetbegović

As a result of mainly German pressure, the EU followed Germany's action and recognised Slovenia and Croatia on 15 January 1992, without any guarantees being given to the Serbs living in Croatia. ${ }^{1}$ The symbolic significance of the event was apparently paid such respect that no actual countermeasures in the event of conflict were prepared. This recognition was as questionable as Germany's, seeing that Croatia was still not being governed in a manner sufficiently satisfactory to preclude internal unrest, particularly bearing in mind the problems inherent in the Krajina region. One should also remember the lack of guarantee to the minorities in

${ }^{1}$ Donia and Fine (1994, p. 233).

(C) The Author(s) 2017 
Croatia mentioned earlier; therefore, the Croatian Serbs could not expect the support of the international community. They were thus forced to seek help from other Serbs, something which the Miloševićcontrolled Yugoslav Army had provided in the form of weapons. For the Serbs cut off in Croatia, Milošević was therefore seen as a man of vision, a defender. To oppose his policies appeared more and more pointless, especially when through his actions and as a symbolic figure, he was supported by a number of actors who did not necessarily have it in mind to help Milošević. In this way, the impression that the move of Milošević to the right on the field was justified was confirmed in practice, and he was now one step ahead. That Milošević's subsequent manipulative manner of introducing violence as a political means can be considered shameful, which is not relevant here. In the local arena, a number of reasonably well-considered moves at the time by Croatia and other countries served to legitimise a shift to the left of the political field.

In this phase, the events displayed in Fig. 7.1 take on a more incisive aspect, with politicians inclined towards constitutional means losing capital in the political field; alternatively, they alter their agenda and move to the right side of the field when they realise that the policies that have polarised on the right are successful. Fighting between Serbs and Croats immediately after Croatia's declaration of independence took place mainly in the Serb-dominated area of the city Knin (Kninska Krajina) in Croatian Dalmatia and also in Slavonia. In January 1992, a ceasefire was agreed upon which then came into force. This opportunity was exploited by transferring troops to Bosnia instead, or, as it might be described, utilising what in clausewitzian terms is called inner lines of communication. Bosnia's president, Izetbegović, failed on Bosnia's behalf to follow up the situation or appreciate the seriousness of disquieting reports of military exercises in Bosnia. ${ }^{2}$

From a military viewpoint, Bosnia was special, with the majority of the Yugoslav defence industry being based there. In addition, Bosnia throughout history, and especially during the partisan fighting of the Second World War, had always been important for the defence of the region. The mountainous and forested terrain of the region made it easy to defend, and it was therefore here that most of the Yugoslav military mobilisation stocks were held; it was planned that the area would act as a

\footnotetext{
${ }^{2}$ Udovicki and Stitkovac (1997, p. 183).
} 
military fulcrum in the event of invasion. ${ }^{3}$ From a doctrinal perspective, giving up Bosnia would be tantamount to surrendering Yugoslavia. This appreciation of Bosnia in the military mind has not been brought out in literature, but it is an important factor if one is to understand the scenario that came to be played out in that constituent republic.

The Badinter Commission's intention to get the referendum in Bosnia as the civil way dealing with Bosnia's partition from Yugoslavia did not occur. The Bosnian Serbs essentially boycotted the voting for Bosnia's independence on 29 February 1992. ${ }^{4}$ In January and February, when they could have taken the political initiative, the EU was waiting for the outcome of a referendum that the Bosnian Serbs had already said they would boycott. ${ }^{5}$ The declaration of the boycott presented an ideal opportunity for the EU to get inside the decision cycles of the parties involved, but instead, they chose to ignore the information. The EU recognised Bosnia on April 6, and USA followed suit the next day. ${ }^{6}$ The Bosnian Serbs' boycott of the referendum was not recorded, and the recognition of the Bosnian state-without the question of the Bosnian Serb position being even discussed-served to legitimise the theory of the Bosnian Serb politician, Radovan Karadžić, that the outside world was against the Serbs. ${ }^{7}$ The trigger for the war in Bosnia was the EU's recognition of the Bosnian state on 6 April 1992.

All was not peaceful in Croatia either. Karadžić became radicalised during the war, playing more and more on racism and cultural differences in his speeches, visiting Orthodox masses to a greater extent, increasingly positive to hostage taking and generally having an uncompromising attitude. ${ }^{8}$ Karadžić, however, was an actor in the political field

\footnotetext{
${ }^{3}$ Donia and Fine (1994, pp. 155 and 174). There was an idea of central defence, striking out of Bosnia. Not dissimilar to Sweden in the 1800s when Sweden's defence policy was based on defence of the central area of Sweden to strike out from. Bosnia's importance for the defence of Yugoslavia can be compared to that of Karlsborg Sweden, and its surroundings.

${ }^{4}$ Donia and Fine (1994, p. 238). See also Sell (2002, p. 163).

${ }^{5}$ Udovicki and Stitkovac (1997, p. 231).

${ }^{6}$ Donia and Fine (1994, p. 236). The authors believe that the USA led this process.

${ }^{7}$ Udovicki and Stitkovac (1997, p. 178).

${ }^{8}$ Owen (1995, p. 301).
} 
by virtue of previously having been a politician, an actor with political capital from politics as a parliamentary practice. Thus, when comparing, for example, Karadžić with Mladić, one finds that these two actors acquired their legitimacy in the political field from different forms of capital, which meant that they could also be influenced in ways that themselves were different. But to do that one must be aware of the mechanics of the field as well as aware of the types of capital the named actors stockpiled. Worthy of mention is that opinion polls reported in the paper Vreme in 1992 showed a slide in SPS popularity and by that also the popularity of Milošević. This was especially true in the cities, in the north of Serbia, and among the educated. Only 15\% of Belgraders supported the SPS compared to $51 \%$ of those in south Serbia. ${ }^{9}$ Milošević no longer held a strong standing among the Serbs in general.

The Bosnian Serb General Mladić, standing as a political force, was greatly improved in power by this change on the field; political power came into his reach as the military power he disposed became legitimate political tools. Mladić's authority as a politician was to a large extent founded on the use of violence as a political means. If that approach became difficult to adopt in the political arena, then Mladić's position would also be undermined. This was something that he himself certainly did not have any problem appreciating, even if that appreciation was not conducted in theoretical terms. In the picture above, Mladic could be replaced with other high-ranking military officers who started to play a political role, ones the field had changed. Sir Rupert Smith describes that Mladić's political power came from the weapons at his disposal, which is in line with the theory described. ${ }^{10}$ Smith also describes how attacks on, for example, Mladić's home village were made in order to undermine the symbolic capital which Mladić had and thereby undermine his power. ${ }^{11}$

When Bosnia was recognised as a state on 6 April 1992, all of a sudden the Yugoslav Army became a foreign army in the region. This happened because the real point at issue had not been debated at an

\footnotetext{
${ }^{9}$ Mann (2005, p. 373).

${ }^{10}$ Smith $(2005$, p. 367). See also Owen (1995). He describes Mladić as a man conducting battles partly like an intellectual, partly like a barbarian, p. 280.

${ }^{11}$ Smith $(2005$, p. 366).
} 
international level, and statements had just been made without further analysis. Proposals from the new government of Bosnia to withdraw were met by the army's reply that $80-90 \%$ of the troops stationed in the area were Bosnian and had no intention of leaving the country. ${ }^{12}$ At the end of April 1992, the Bosnian Serbs took control of the Banja-Luka area in Bosnia and almost immediately started using the former local Yugoslav TV substation to spread war propaganda. ${ }^{13} \mathrm{~A}$ duel was conducted during the war in Bosnia between the TV channels of the different (political) camps, and a mortar attack on a bread queue in Sarajevo, for instance, being given a different slant by both TV Sarajevo and TV Pale. ${ }^{14}$ It is also worth noting that Bosnian TV was also used as an instrument of propaganda, promoting the idea, for example, that the war was being waged by people who did not live in Bosnia. This was a lie, even if volunteers from mainly Croatia and Serbia were represented among the fighting elements. ${ }^{15}$ In May 1992, 38 generals were purged from the JNA to establish Serbian control. ${ }^{16}$ The Bosnian politicians driving forward the move towards independence should most certainly have understood that this situation would arise, and they were playing a dangerous game. The Bosnian President, and the leader of the Bosnian Muslim Party, Alija Izetbegović, chose to declare Bosnia independent, inspired by the example set by Croatia, despite other Bosnian Muslim voices warning against it. ${ }^{17}$ Izetbegović apparently misjudged the situation in a grave way. It is also relevant that the Bosnian Serb leader, Karadžić, had not been at all unclear on the issue of what Bosnia could expect if it happened to declare independence. ${ }^{18}$ The situation in Bosnia was much different compared to Croatia and Slovenia, as Robert Hayden discusses. ${ }^{19}$

\footnotetext{
${ }^{12}$ Sikavica (1997, p. 146).

${ }^{13}$ Udovicki and Stitkovac (1997, p. 187).

${ }^{14}$ Udovicki and Torov (1997, p. 121).

${ }^{15}$ Loc. cit.

${ }^{16}$ Mann (2005, p. 394).

${ }^{17}$ Udovicki and Stitkovac (1997, p. 175) [Nadezda Gace, "Velika Srbija na mala vrata" Vreme 911127, p. 27].

${ }^{18}$ Udovicki and Stitkovac (1997, p. 179) [Roksanda Nincic et al., "Drina bez Cuprije" Vreme (weekly anti-war publication, Belgrade), 911021, p. 20].

${ }^{19}$ Hayden (1992, p. 661).
} 
The new Bosnian state did not control most of its territory, which really should not come as a surprise to any of those who recognised the state. That knowledge combined with the recent acts of violence in former Yugoslavia should have been enough of a warning of the events to unfold.

Even though David Owen had good experience of Alija Izetbegović, he did not hesitate to mention that this opinion of Izetbegović was not shared by others. Manipulative and untrustworthy are labels which were used. But his indecision, which has been mentioned above, is also mentioned along with fundamentalistic advisors. ${ }^{20}$ Owen describes Izetbegović's party SDA as increasingly intolerant, which fits very well into the theoretical picture above (Fig. 7.1). In order to keep being a political factor, one has an easy option to allow oneself to be radicalised by the conflict. ${ }^{21}$ One can also note that the Bosnian Muslims did not identify themselves very much as Muslims before the war, and the genocide of them changed that. ${ }^{22}$ The logic of practice changed the perception of the self so that the Bosnian Muslims restructured themselves. The former deputy of Carl Bildt-the first high representative for Bosnian peace implementation-Louis Sell confirms this with stating that Izetbegović called for a creation of a Muslim federation from Indonesia to Morocco and that media only should be entrusted to people of "deeply Islamic faith". ${ }^{23}$

Izetbegović's not being able to judge the situation correctly may perhaps be explained by the fact that he had poor contact with the Bosnian people outside Sarajevo, a city that was to a marked degree multi-ethnic and not representative of the rest of Bosnia. In any event, he placed far too much hope on the international community's will and ability to intervene. In addition, he had the task of representing different sections of Muslim political persuasion, something that contributed further to the image of him as indecisive. ${ }^{24}$ Owen thinks that Sarajevo was besieged by both Serbs and the Bosniacs, who got political leverage by having the Serbs continue besieging the city. People were not allowed to leave the

\footnotetext{
${ }^{20}$ Owen $(1995$, p. 38).

${ }^{21}$ Owen $(1995$, p. 40). See also Sell $(2002$, p. 5$)$.

${ }^{22}$ Gagnon (2004, p. 27).

${ }^{23}$ Sell (2002, p. 158).

${ }^{24}$ de Graaff (2003, p. 114).
} 
city as the political positive effect for the besieged would dwindle by that. ${ }^{25}$ There was also documentation of beleaguered Bosniacs drawing Serbian fire on a hospital by placing mortars behind it, and sniper fire on civilians in the city from a building controlled by the Bosnian Government. ${ }^{26}$ This theory is plausible as it was a political decision, top down, to use the citizens of Sarajevo as a means of politics; it was not the people who put themselves in the line of fire. The Bosnian politics had hardly any other cards to play than the card of inciting the picture of suffering and lack of power, towards the international community, and this was one of a few viable ways to conduct international politics for Izetbegović and his allies.

This still did not ring enough alarm bells for the Bosnian and international politicians who chose to act, ignoring the statement by the Badinter Commission affirming the need for all three ethnic groups to be well-represented in order for the referendum to be considered valid. This was certainly evident when the Bosnian Muslim leader Izetbegović, under the influence of the USA, withdrew from the EU-supported Lisbon agreement in 28 March 1992, which would have divided Bosnia into cantons - both the Croats and Serbs agreed to this. The USA tolerated the Bosnian Muslims covertly importing weapons from Iran and other Muslim countries. ${ }^{27}$ The Croatians, on the other hand, evaded the arms embargo (despite the ineffective resolution UNSCR 713) and equipped both themselves and the Bosniacs with arms as no UN surveillance existed between Posavina and Western Herzegovina. ${ }^{28}$ The recently reunited Germany had no use for the old Eastern German munitions it had inherited, but Germany had a political agenda in Yugoslavia. Croatia had the opportunity, despite the embargo, to buy former DDR heavy artillery and tanks with other countries as middlemen. This of course stiffened Serbian resistance against demilitarisation, for they still had

\footnotetext{
${ }^{25}$ Owen (1995, p. 59). One can also note a sniper incident at Sarajevo, performed by Bosniacs, killing an UNPROFOR soldier on 8 September 1992. Apparently, it was done as an attempt to make it look like a Serbian attack, as the soldier was escorting food to the beleaguered Sarajevo. Owen (1995, p. 44).

${ }^{26}$ Owen $(1995$, p.106).

${ }^{27}$ Sell (2002, p. 224).

${ }^{28}$ Owen (1995, pp. 45, 47 and 315).
} 
a weapon embargo. ${ }^{29}$ The situation did a lot to further restructure the political field in the remaining Yugoslavian area as it was clear that the international community was more against Serbia than was neutral.

All of this is important for outsiders to understand if we in the future intend to intervene in situations that might involve the deployment of troops. The EU and the USA maybe found it more difficult to see the problems in Bosnia, especially when the separatist Bosnian politicians did not raise the issues at the international level. But more caution could most certainly have been exercised in the period before Bosnia declared independence. The signals from the Bosnian Serbs had been clear at the time of the referendum. There existed an imbalance in the capacity for violence that favoured the Bosnian Serb minority. This made a violent interpretation of the field more likely. An important part of the collective habitus in the scenario is Yugoslavia's violent recent past with infighting and ethnic cleansing during World War II, where the capacity for violence became a legitimate form of political capital. In addition, the party system in Bosnia followed ethnic and not ideological patterns; the choice of nationalist party programme was geared to ethnic origin. ${ }^{30}$ Tudjman has been described as having power over the political discourse and changing it into a hostile one regarding ethnic origin in particular. This in its turn could "enhance one's status in the community". ${ }^{31}$ This can easily be seen as a social field where the actors with consecrating power restructure the field, and other actors either follow the new structure with their power intact or strengthened, or they resist and might eventually lose power as the new structure does not support their choice (a conscious choice or not).

The idea of ethnic background dictating dividing lines was nothing new for Bosnia as part of the former Yugoslavia, but it stands to reason that one can clearly expect problems in a republic that has aspirations of independence and that at the same time has ethnic diversity considered to be an inherent political issue by all major parties. Added to this, the neighbouring countries with the same ethnic diversity had waged a war

\footnotetext{
${ }^{29}$ Owen (1995, pp. 70 and 74). See also p. 120 for reference that even the Bosniacs had gathered an arsenal of quite some substance in 1995. In all honesty, the Serbs had a lot of the old Yugoslavian weapon production capacity under control, so they needed allies less than others in this respect.

${ }^{30}$ Udovicki and Stitkovac (1997, p. 175).

${ }^{31}$ Sekulic et al. (2006, p. 822).
} 
along the same lines the year before. Given this scenario, there existed considerable potential for disaster.

The different opinions among the involved nations about what should be done were also a dilemma and a root for inaction and problems. The opinion in the USA was strongly anti-Serbian, which in its turn damaged the credibility of the peace brokers Cyrus Vance and David Owen and their attempts to negotiate a peace. ${ }^{32}$ The Croats and Bosniacs received signals that they had an opportunity for a better deal by the USA than by VanceOwen. The Serbs on the other hand saw that there was no united front among the European countries and certainly not in relation to the USA.

\section{BIBLIOGRAPHY}

Donia, R., \& Fine, J. (1994). Bosnia and Herzegovina. A tradition betrayed. London: Colombia University Press.

Gagnon, V. P. (2004). The myth of the ethnic war. Serbia and Croatia in the 1990s. Ithaca: Cornell University Press.

Graaff de, B. (2003). The wars in former Yugoslavia in the 1990s: Bringing the state back in. In J. Ångström \& I. Duyvesteyn (Eds.), The nature of modern war: Clausewitz and his critics revisited. Stockholm: Swedish National Defence College.

Hayden, R. (1992). Nationalism in the former Yugoslav Republics. Slavic Review, 5I(4) (Cambridge).

Mann, M. (2005). The dark side of democracy. Explaining ethnic cleansing. Cambridge: Cambridge University Press.

Owen, D. (1995). Balkan odyssey. London: Harvest Book.

Sekulic, D., et al. (2006). Ethnic intolerance and ethnic conflict in the dissolution of Yugoslavia. Ethnic and Racial Studies, 29, 5 (New York: Routledge).

Sell, L. (2002). Slobodan Miloševic and the destruction of Yugoslavia. Durham: Duke University Press.

Sikavica, S. (1997). The armys collapse. In J. Udovicki \& J. Ridgeway (Eds.), Burn this house. The making and unmaking of Yugoslavia. Durham: Duke University Press.

Smith, R. (2005). The utility of force. The art of war in the modern world. London: Penguin Books.

${ }^{32}$ Owen (1995, pp. 100, 107, 136 and 295). 
Udovicki, J., \& Stitkovac, E. (1997). “Bosnia and Hercegovina: The Second War” burn this house. In J. Udovicki \& J. Ridgeway (Eds.), The Making and Unmaking of Yugoslavia. Durham \& London: Duke University Press.

Udovicki, J., \& Torov, I. (1997). The interlude. In J. Udovicki \& J. Ridgeway (Eds.), Burn this house. The making and unmaking of Yugoslavia. Durham: Duke University Press.

Open Access This chapter is licensed under the terms of the Creative Commons Attribution 4.0 International License (http://creativecommons. org/licenses/by/4.0/), which permits use, sharing, adaptation, distribution and reproduction in any medium or format, as long as you give appropriate credit to the original author(s) and the source, provide a link to the Creative Commons license and indicate if changes were made.

The images or other third party material in this chapter are included in the chapter's Creative Commons license, unless indicated otherwise in a credit line to the material. If material is not included in the chapter's Creative Commons license and your intended use is not permitted by statutory regulation or exceeds the permitted use, you will need to obtain permission directly from the copyright holder.

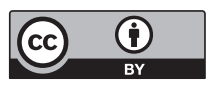

